\title{
Efektivitas Sistem Pengelolaan Sampah Berbasis Masyarakat (Studi Kasus: Desa Sanur Kaja Kota Denpasar)
}

\section{The Effectiveness of Community Based Waste Management Systems (Case Study: Sanur Kaja Village, Denpasar City)}

\author{
Ni Putu Amelia Panida Dewi, Ida Ayu Gede Bintang Madrini*, I Wayan Tika \\ Program Studi Teknik Pertanian dan Biosistem, Fakultas Teknologi Pertanian Universitas Udayana, Badung, Bali, \\ Indonesia \\ *email: bintangmadrini@unud.ac.id
}

\begin{abstract}
Abstrak
Desa Sanur Kaja memiliki satu depo pengelolaan sampah khusus untuk menangani sampah yang dihasilkan oleh masyarakat desa yang bernama Depo Cemara. Berdasarkan penelitian sebelumnya diketahui bahwa kegiatan yang berjalan di Depo Cemara menjadi kurang efisien karena salah satu aspek penilaian yaitu terpilahnya sampah dan penerapan prinsip 3R (reduce, reuse, dan recycle) pada sumbernya belum dilakukan dengan optimal. Penelitian ini bertujuan untuk mengidentifikasi sejauh mana efektivitas sistem pengelolaan sampah yang sudah dilakukan oleh masyarakat Desa Sanur Kaja dengan membandingkan jumlah sampah yang dikelola oleh rumah tangga dengan prinsip $3 \mathrm{R}$ dengan jumlah sampah yang terbuang sehingga diperoleh persentase reduksi sampah. Pengumpulan data diperoleh dengan menyebar kuesioner mengenai pengelolaan sampah rumah tangga kepada responden yang ditentukan dengan teknik purposive sampling. Data yang diperoleh kemudian dihitung dengan analisis kesetimbangan massa sampah lalu dianalisis lebih lanjut dengan metode analisis statistik deskriptif. Hasil penelitian terhadap 96 rumah tangga menunjukkan bahwa pengelolaan sampah berbasis masyarakat memiliki efektivitas yang rendah karena reduksi sampah yang terjadi hanya $22,5 \%$ dalam satu hari dan responden yang melakukan pemilahan sampah rumah tangga sebanyak $44 \%$. Masyarakat menyatakan setuju terhadap rencana penerapan prinsip $3 \mathrm{R}$ dalam pengelolaan sampah rumah tangga serta menganggap penting ditambahkannya fasilitas-fasilitas pendukung pengelolaan sampah.
\end{abstract}

Kata kunci: efektivitas, pengelolaan sampah berbasis masyarakat, prinsip $3 R$.

\begin{abstract}
Sanur Kaja Village has a special waste management facility for processing waste produced by the village community, namely Depo Cemara. Based on previous research on the effectiveness of waste management in the Depo Cemara, it is known that in general these activities have been running well but are less efficient. This is because of the community has not done waste sorting and the application of the $3 \mathrm{R}$ principle at its source, which this is one of the assessment aspects. This study aims to identify the effectiveness of the waste management system that has been implemented by the people of Sanur Kaja Village by comparing the amount of waste managed by households with the 3R principle with the amount of waste wasted in order to obtain a percentage of waste reduction. Data collection was obtained by distributing questionnaires to respondents who were determined by purposive sampling technique. The data obtained were then calculated by analyzing the mass balance of waste and then further analyzed using descriptive statistical analysis methods. The results of research on 96 households show that community-based waste management is still not effective because the percentage of waste reduction that occurs in one day only $22,5 \%$ and respondents who sort household waste are $44 \%$. The community agreed to the plan to implement the 3R principle in household waste management and considered it important to add supporting facilities for waste management.
\end{abstract}

Keywords: effectiveness, community based waste management, $3 R$ concept.

\section{PENDAHULUAN}

Keberadaan sampah dalam jumlah banyak jika tidak dikelola dengan baik akan menimbulkan berbagai permasalahan seperti pada kondisi lingkungan, kesehatan, sosial ekonomi serta budaya di masyarakat (Wardi, 2011). Daerah perkotaan umumnya didominasi oleh permukiman serta terdiri dari banyak 
pusat kegiatan sehingga bisa menghasilkan sampah dalam jumlah banyak. Menurut Madrini (2016), manusia mampu menghasilkan sampah sebanyak 0,8 - $1 \mathrm{~kg} / \mathrm{kapita} / \mathrm{hari}$ dimana angka ini akan menjadi suatu masalah jika tidak ditangani dengan serius. Jumlah limbah juga akan terus meningkat setiap tahunnya sejalan dengan meningkatnya jumlah penduduk dan kualitas kehidupan masyarakat atau manusianya dan disertai juga dengan kemajuan ilmu pengetahuan dan teknologi yang berdampak pada pergeseran pola hidup menjadi lebih konsumtif (Sahil et al., 2016).

Desa Sanur Kaja merupakan salah satu wilayah permukiman yang terletak di Kecamatan Denpasar Selatan, Kota Denpasar. Desa Sanur Kaja memiliki satu tempat pengolahan sampah terpadu yang bernama Depo Cemara. Sampah yang dihasilkan oleh masyarakat Desa Sanur Kaja dikumpulkan dan diolah di Depo Cemara terlebih dahulu sebelum dibuang ke TPA (Tempat Pembuangan Akhir). Depo Cemara menerapkan sistem pengelolaan sampah dengan prinsip 3R (reduce, reuse, dan recycle) yang bertujuan untuk mengurangi jumlah sampah yang terbuang ke TPA. Berdasarkan kriteria penilaian manajemen pengelolaan sampah, secara umum Depo Cemara telah menerapkan prinsip 3R namun pelaksanaannya kurang optimal karena pengelolaan sampah pada sumbernya yang belum terlaksana (Putranto, 2015). Hasil survei sosial ekonomi nasional tahun 2017 juga menunjukkan hal serupa, yaitu diketahui bahwa persentase rumah tangga di Indonesia yang melakukan daur ulang sampah hanya sebesar $0,1 \%$, rumah tangga yang melakukan pengomposan sebesar $0,6 \%$ dan rumah tangga yang menyetorkan sampah ke bank sampah sebesar $0,4 \%$ (Badan Pusat Statistik, 2018).

Pengelolaan sampah yang tepat dilakukan secara sinergis dan terintegrasi sehingga berjalan efektif dan mampu mencapai tujuan yaitu target reduksi sampah di setiap daerah. Mengacu pada SNI 3242:2008 Tentang Pengelolaan Sampah di Permukiman, masyarakat sebagai sumber timbulan sampah seharusnya terlibat dalam kegiatan pengelolaan sampah yang terdiri dari melakukan pemilahan di sumbernya, melakukan pengolahan sampah dengan prinsip 3R, wajib membayar retribusi sampah, menjaga kebersihan lingkungan, mematuhi aturan pembuangan sampah serta aktif dalam sosialisasi pengelolaan sampah di lingkungannya. Menurut Sukerti et al. (2017), pengelolaan sampah dengan prinsip 3R di rumah tangga perlu diterapkan secara komprehensif untuk meminimalkan timbulan sampah dan memaksimalkan partisipasi masyarakat. Salah satu analisis yang dilakukan oleh Riswan tahun 2012 pada penelitiannya mengenai pengelolaan sampah rumah tangga dengan 3R di Kecamatan Daha Selatan, diasumsikan bahwa terjadi penurunan volume sampah sebesar sembilan persen setiap tahunnya dengan perhitungan menggunakan rata-rata pertumbuhan penduduk $0,57 \%$ per tahun (Riswan et al., 2012).

Dalam pengelolaan sampah berbasis masyarakat, tujuan yang ingin dicapai yaitu reduksi jumlah sampah yang berakhir di TPA. Tujuan tersebut dapat tercapai apabila masyarakat melakukan pemilahan sampah dan menerapkan prinsip 3R mulai dari rumah tangga seperti mengurangi penggunaan barang sekali pakai (reduce), memanfaatkan kembali barang yang masih layak pakai (reuse), dan mengolah sampah menjadi produk baru yang bermanfaat (recycle) sehingga sampah yang akan dibawa menuju TPA menjadi lebih sedikit dibandingkan dengan jumlah sampah yang dihasilkan. Jika kondisi tersebut tercapai maka efektivitas dari sistem pengelolaan sampah berbasis masyarakat akan meningkat. Menurut Winarsih et al. (2019), efektivitas dari suatu sistem merupakan taraf tercapainya tujuan yang diinginkan oleh sistem tersebut sehingga semakin besar persentase target yang dicapai maka semakin tinggi pula efektivitasnya.

Meninjau penjelasan di atas, pengelolaan sampah berbasis masyarakat sangat diperlukan untuk mendukung kinerja Depo Cemara sebagai tempat pengolahan sampah terpadu yang sudah ada di Desa Sanur Kaja serta untuk menjaga kebersihan dan kesehatan lingkungan di sekitarnya. Maka dari itu penelitian ini dilakukan untuk mengidentifikasi tingkat efektivitas pengelolaan sampah berbasis masyarakat yang dilakukan oleh rumah tangga di Desa Sanur Kaja dengan cara membandingkan jumlah sampah yang direduksi dan total sampah yang dihasilkan. Penelitian ini diharapkan dapat bermanfaat bagi pemerintah setempat dalam mengambil keputusan mengenai penerapan prinsip 3R di rumah tangga. Peran serta masyarakat dalam mengelola sampah rumah tangga seperti upaya pemilahan sampah, penerapan prinsip $3 R$ serta persentase penurunan jumlah sampah menuju Depo Cemara dalam kurun waktu tertentu menjadi fokus utama dalam penelitian ini.

\section{METODE}

\section{Tempat dan Waktu Penelitian}

Pengumpulan data dengan menggunakan kuesioner dilakukan secara daring di delapan dusun yang berada di Desa Sanur Kaja Kota Denpasar, yaitu Dusun Belong, Dusun Pekandelan, Dusun Batanpoh, Dusun Anggarkasih, Dusun Buruwan, Dusun Tegal Asah, 
Dusun Wirasana, dan Dusun Langon. Penelitian ini dilaksanakan pada bulan Agustus sampai dengan Oktober 2020.

\section{Populasi dan Responden}

Populasi yang digunakan dalam penelitian ini yaitu keluarga yang berdomisili di Desa Sanur Kaja Kota Denpasar dan responden yang terlibat dalam penyebaran kuesioner ditentukan dengan teknik purposive sampling, yaitu mengambil sampel dari populasi yang ada dimana sampel memiliki kriteria atau pertimbangan tertentu yang sesuai dengan fokus penelitian seperti kriteria umur, budaya, pekerjaan maupun pengalaman tertentu (Etikan et al., 2016). Pertimbangan yang ditentukan untuk responden dalam penelitian ini yaitu responden adalah keluarga yang tidak memiliki home industry atau usaha apapun yang dikerjakan di rumah. Jumlah populasi rumah tangga di Desa Sanur Kaja yaitu sebanyak 1.658 KK sehingga untuk mengetahui jumlah sampel minimal yang dicari ditentukan dengan rumus Slovin seperti pada persamaan 1 (Setiawan, 2007).

$\mathrm{n}=\frac{N}{1+N e^{2}}$

Keterangan:

$\mathrm{n}=$ ukuran sampel minimal

$\mathrm{N}=$ ukuran populasi

$\mathrm{e}=$ peluang kesalahan $(10 \%)$

\section{Jenis Data}

Jenis data yang dikumpulkan dalam penelitian ini yaitu data kualitatif dan kuantitatif. Yang termasuk data kualitatif dalam penelitian ini yaitu perilaku masyarakat dalam mengelola sampah rumah tangga dan ekpektasi masyarakat terhadap pengelolaan sampah rumah tangga di Desa Sanur Kaja Kota Denpasar. Sedangkan data kuantitatif dalam penelitian ini yaitu tingkat pengetahuan masyarakat terhadap prinsip 3R, jumlah dan jenis sampah rumah tangga yang dihasilkan per KK/hari, serta persentase masyarakat yang menerapkan prinsip 3R.

\section{Variabel Penelitian}

Variabel-variabel yang diamati dalam penelitian ini diantaranya yaitu pengetahuan masyarakat terhadap prinsip $3 \mathrm{R}$, perilaku masyarakat dalam mengelola sampah rumah tangga sesuai dengan prinsip 3R, jumlah dan komposisi sampah yang dihasilkan per $\mathrm{KK} /$ hari, persentase $\mathrm{KK}$ yang menerapkan prinsip 3R, serta ekspektasi masyarakat terhadap sistem pengelolaan sampah berbasis masyarakat. Pengetahuan masyarakat terhadap prinsip 3R merupakan pemahaman responden mengenai pengelolaan sampah pada sumbernya dengan menerapkan prinsip 3R. Perilaku masyarakat dalam mengelola sampah rumah tangga merupakan tindakan atau perlakuan masyarakat terhadap sampah yang dihasilkan sesuai dengan prinsip 3R. Ekspektasi masyarakat terhadap sistem pengelolaan sampah yang dimaksud adalah harapan masyarakat mengenai penerapan prinsip 3R di rumah tangga dan fasilitas pendukung yang diinginkan untuk memudahkan pengelolaan sampah berbasis masyarakat.

\section{Metode Pengumpulan Data}

Pengumpulan data dilakukan dengan cara menyebarkan kuesioner kepada 96 KK di Desa Sanur Kaja yang mana pada masing-masing dusun dicari sebanyak $12 \mathrm{KK}$ sebagai responden agar data yang diperoleh dapat mewakili keseluruhan dusun yang ada. Pengumpulan data dilakukan pada saat pandemi sehingga kuesioner disebarkan secara daring melalui platform Google Form. Kuesioner yang digunakan dalam pengumpulan data terdiri dari 32 butir pertanyaan yang berkaitan dengan variabel penelitian. Adapun aspek yang ditanyakan dalam kuesioner mengenai pengetahuan masyarakat yaitu pemahaman terhadap uraian kegiatan $3 \mathrm{R}$ dan pengelolaan sampah berbasis masyarakat. Aspek yang ditanyakan mengenai perilaku masyarakat dalam mengelola sampah rumah tangga yaitu kegiatan pemilahan sampah dan perlakuan prinsip 3R terhadap sampah yang sudah terpilah. Aspek yang ditanyakan mengenai jumlah dan komposisi sampah yaitu uraian jenis-jenis sampah rumah tangga yang dihasilkan serta perkiraan massa sampah dalam satu hari. Aspek yang ditanyakan mengenai ekspektasi masyarakat yaitu harapan masyarakat terhadap pengelolaan sampah dengan prinsip $3 \mathrm{R}$ di rumah tangga dan fasilitas-fasilitas pendukung.

\section{Analisis Data}

Penelitian ini menggunakan metode analisis statistik deskriptif untuk membahas dan menelaah lebih lanjut hasil olah data yang diperoleh. Statistik yang digunakan untuk mengolah data hasil penelitian ini yaitu mean (rata-rata), jumlah (total), modus, dan persentase. Dalam penelitian ini, untuk mengukur tingkat pengetahuan masyarakat mengenai prinsip $3 \mathrm{R}$ 
digunakan persamaan 2. Hasil perhitungan yang diperoleh dibandingkan dengan katagori tingkat pengetahuan seseorang menurut Marita (2013), yang mana terdiri dari tiga katagori yaitu tingkat pengetahuan baik jika nilainya $\geq 76-100$ persen, tingkat pengetahuan cukup jika nilainya 56-75 persen, dan tingkat pengetahuan kurang jika nilainya $\leq 55$ persen.

Nilai pengetahuan $=\frac{\text { Jumlah jawaban benar }}{\text { Total soal }} \times 100 \%$

Perilaku masyarakat dalam mengelola sampah yang diidentifikasi dalam penelitian ini yaitu perilaku pemilahan sampah dan pengelolaan terhadap sampah yang terpilah. Perilaku masyarakat dalam pemilahan sampah yaitu membedakan wadah atau tempat sampah berdasarkan jenisnya. Dalam penelitian ini perilaku masyarakat dalam pemilahan sampah diukur dengan cara menghitung jumlah responden yang melakukan pemilahan sampah berdasarkan jenisnya. Pengelolaan terhadap sampah yang sudah terpilah merupakan kegiatan lanjutan dari pemilahan sampah yang dijabarkan menjadi lima kegiatan, yaitu mengurangi penggunaan barang sekali pakai, pemanfaatan barang kembali, pengomposan sampah organik, daur ulang dan penjualan sampah anorganik. Persentase rumah tangga yang mengelola sampah terpilah diperoleh dengan menggunakan persamaan 3 (Badan Pusat Statistik, 2015).

$\% \operatorname{gbg}=\frac{\sum \mathrm{Rgbg}}{\sum \mathrm{RT}} \times 100 \%$

Keterangan:

$\% \mathrm{gbg}=$ persentase rumah tangga yang mengelola sampah terpilah

$\sum \mathrm{Rgbg}=$ jumlah rumah tangga yang mengelola sampah terpilah

$\sum \mathrm{RT}=$ jumlah rumah tangga yang memilah sampah

Dalam mengidentifikasi persentase jenis-jenis sampah rumah tangga yang dihasilkan, dilakukan perhitungan terhadap jumlah responden yang menyatakan menghasilkan jenis sampah tertentu. Persentase jenis sampah yang dihasilkan diperoleh melalui persamaan 4. Jumlah sampah rumah tangga yang dihasilkan oleh responden dalam satu hari dihitung dengan cara mengalikan data massa sampah dan jumlah rumah tangga. Data massa sampah diperoleh melalui pengisian kuesioner dengan asumsi responden mampu memperkirakan berat sampah yang dihasilkan di rumah dalam satu hari. Responden diberikan pilihan rentang massa sampah pada kuesioner mulai dari 0,5-1 kg/hari, 1-2 kg/hari, 2-3 $\mathrm{kg}$ /hari, 3-4 kg/hari, 4-5 kg/hari, dan $>5 \mathrm{~kg} / \mathrm{hari}$ sehingga hasil perhitungan yang diperoleh yaitu jumlah sampah minimal dan maksimal dalam satu hari. Rata-rata total sampah yang dihasilkan responden dalam satu hari diperoleh dengan menggunakan persamaan 5 .

$\%$ jenis sampah $=\frac{\text { Responden penghasil jenis sampah }}{\text { Total responden }} \times 100 \%$ [4]

$\bar{X}$ sampah $=\frac{\sum \text { Sampah minimal }+\sum \text { Sampah maksimal }}{2}[5]$

Keterangan:

$\bar{X}$ sampah $\quad=$ rata-rata total sampah

$\sum$ sampah minimal $=$ jumlah sampah minimal yang dihasilkan dalam satu hari

$\sum$ sampah maksimal $=$ jumlah sampah maksimal yang dihasilkan dalam satu hari

Dalam mengukur efektivitas sistem pengelolaan sampah pada penelitian ini diperlukan nilai persen reduksi sampah yang menunjukkan persentase sampah tereduksi melalui penerapan $3 \mathrm{R}$ di rumah tangga. Jumlah sampah yang tereduksi adalah jumlah sampah yang tidak terbuang ke Depo Cemara melalui kegiatan pengomposan sampah organik, daur ulang dan penjualan sampah anorganik. Jumlah sampah yang tereduksi dalam satu minggu dihitung dengan cara mengalikan data massa sampah dan jumlah rumah tangga. Responden diberikan pilihan rentang massa sampah pada kuesioner mulai dari 0,5-1 $\mathrm{kg} /$ minggu, $1-2 \mathrm{~kg} /$ minggu, 2-3 kg/minggu, 3-4 $\mathrm{kg}$ /minggu, 4-5 kg/minggu, dan $>5 \mathrm{~kg} /$ minggu sehingga hasil perhitungan yang diperoleh yaitu jumlah reduksi sampah minimal dan maksimal dalam satu minggu. Rata-rata jumlah sampah yang tereduksi diperoleh dengan menggunakan persamaan 5 sedangkan nilai persen reduksi diperoleh dengan menggunakan persamaan 6 (Triana dan Sembiring, 2019). Analisa kesetimbangan massa sampah digunakan untuk mengetahui jumlah sampah residu yang tidak bisa dimanfaatkan sehingga harus terbuang ke Depo Cemara. Secara umum, persamaan 
dalam kesetimbangan sampah dijabarkan pada persamaan 7 (Radityaningrum et al., 2017).

$\%$ reduksi sampah $=\frac{\text { Jumlah reduksi sampah }}{\text { Total sampah }} \times 100 \%[6]$

$\sum$ sampah $=$ reduksi sampah + sampah residu

Keterangan:

Esampah = jumlah seluruh sampah rumah tangga yang dihasilkan ( $\mathrm{kg} / \mathrm{hari})$

Reduksi sampah $=$ jumlah sampah yang dikelola di rumah tangga $(\mathrm{kg} / \mathrm{hari})$

Sampah residu $=$ jumlah sampah yang tidak dapat dikelola oleh rumah tangga ( $\mathrm{kg} / \mathrm{hari})$

HASIL DAN PEMBAHASAN

Tingkat Pengetahuan Masyarakat Mengenai Pengelolaan Sampah Berbasis Masyarakat
Menurut Susanto et al. (2010), tingkat pengetahuan masyarakat mengenai pengelolaan sampah berpengaruh signifikan terhadap perilaku pengelolaan sampah. Perhitungan tingkat pengetahuan masyarakat mengenai pengelolaan sampah berbasis masyarakat dilakukan dengan menggunakan persamaan 2. Berdasarkan hasil penelitian terhadap pengetahuan masyarakat mengenai pengelolaan sampah berbasis masyarakat, dari 96 orang responden di Desa Sanur Kaja terdapat 70 orang memiliki pengetahuan yang baik, 14 orang berpengetahuan cukup, dan 12 orang berpengetahuan kurang (Gambar 1). Mayoritas masyarakat Desa Sanur Kaja memahami dengan baik mengenai dasar pengelolaan sampah berbasis masyarakat dengan prinsip 3R. Adapun faktor-faktor yang mempengaruhi tingkat pengetahuan seseorang yaitu pendidikan, usia, lingkungan, dan sosial budaya. Semakin tinggi tingkat pendidikan seseorang maka semakin tinggi pula tingkat pengetahuannya (Wawan dan Dewi, 2011).

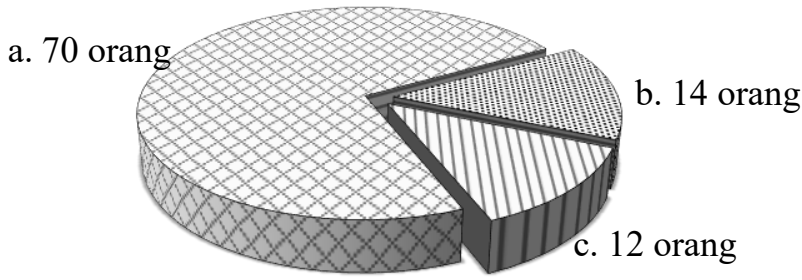

$\triangle$ a. Masyarakat berpengetahuan baik $(\geq 76-100 \%)$

国 b. Masyarakat berpengetahuan cukup (56-75\%)

$\square$ c. Masyarakat berpengetahuan kurang $(\leq 55 \%)$

Gambar 1. Tingkat pengetahuan masyarakat Desa Sanur Kaja mengenai pengelolaan sampah berbasis masyarakat.

Perilaku Masyarakat dalam Mengelola Sampah Rumah Tangga

Perilaku merupakan cerminan sikap dari interaksi antara manusia dengan lingkungan di sekitarnya. Menurut Sasanto dan Purwanti (2011) perilaku yang baik dalam mengelola sampah rumah tangga yaitu melakukan pemilahan sampah yang sesuai dengan penerapan prinsip $3 \mathrm{R}$ seperti mengurangi penggunaan barang sekali pakai (reduce), memanfaatkan kembali barang untuk fungsi yang sama atau lainnya (reuse), dan mendaur ulang sampah organik maupun anorganik (recycle). Berdasarkan hasil survei yang dilakukan di Desa Sanur Kaja, diketahui bahwa masyarakat sudah melakukan pemilahan sampah namun belum berdasarkan prinsip 3R. Dari 96 rumah tangga yang menjadi responden, sebanyak 54 rumah tangga tidak melakukan pemilahan sampah dan 42 rumah tangga melakukan pemilahan sampah. Dari 42 rumah tangga yang melakukan pemilahan sampah, sebanyak 36 rumah tangga memilah sampah berdasarkan dua jenis yaitu organik dan anorganik, sedangkan sebanyak enam rumah tangga memilah berdasarkan tiga jenis sampah, yaitu organik, anorganik dan residu (Gambar 2). Menurut Sukerti et al. (2017), terdapat faktor internal dan faktor eksternal yang mempengaruhi tinggi rendahnya persentase pengelolaan sampah berbasis masyarakat dengan prinsip 3R. Faktor internal di antaranya yaitu tingkat pengetahuan masyarakat terhadap pengelolaan sampah dengan 
prinsip 3R dan jenjang pendidikan, pendapatan, dan waktu luang. Sedangkan faktor eksternal di antaranya meliputi sarana dan prasarana, sosialisasi, serta adanya aturan atau hukum yang secara resmi mengatur perilaku masyarakat terhadap pengelolaan sampah.

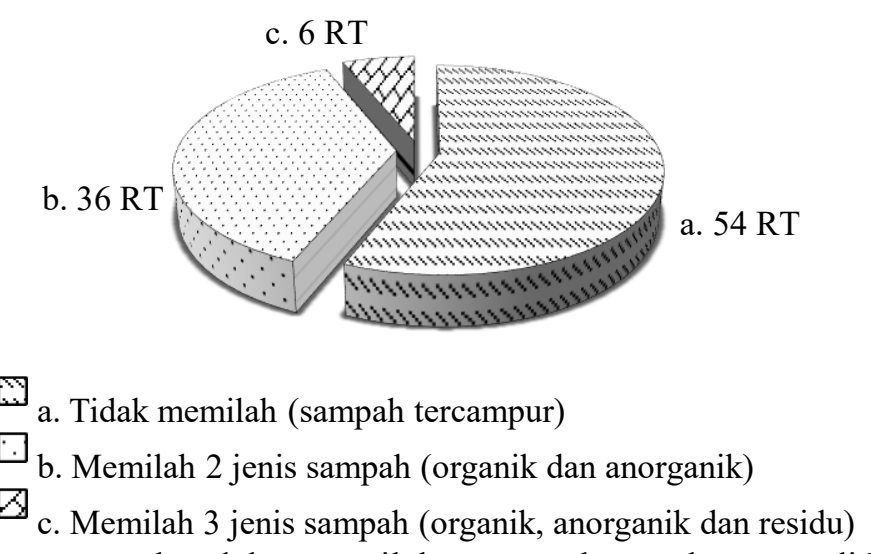

Gambar 2. Perilaku masyarakat dalam pemilahan sampah rumah tangga di Desa Sanur Kaja.

Dalam penelitian ini persentase rumah tangga yang mengelola sampah diperoleh melalui persamaan 3 . Berdasarkan hasil survei terhadap 42 rumah tangga yang melakukan pemilahan sampah, diperoleh persentase rumah tangga yang mengelola sampah seperti pada Gambar 3. Kegiatan mengurangi penggunaan barang sekali pakai dilakukan oleh 35 rumah tangga $(83,3 \%)$, kegiatan penggunaan kembali barang yang masih layak pakai dilakukan oleh 37 rumah tangga $(88,1 \%)$, kegiatan pengomposan dilakukan oleh 24 rumah tangga (57,1\%), kegiatan daur ulang sampah anorganik dilakukan oleh 11 rumah tangga $(26,2 \%)$, dan kegiatan menjual sampah anorganik dilakukan oleh 30 rumah tangga $(71,4 \%)$.

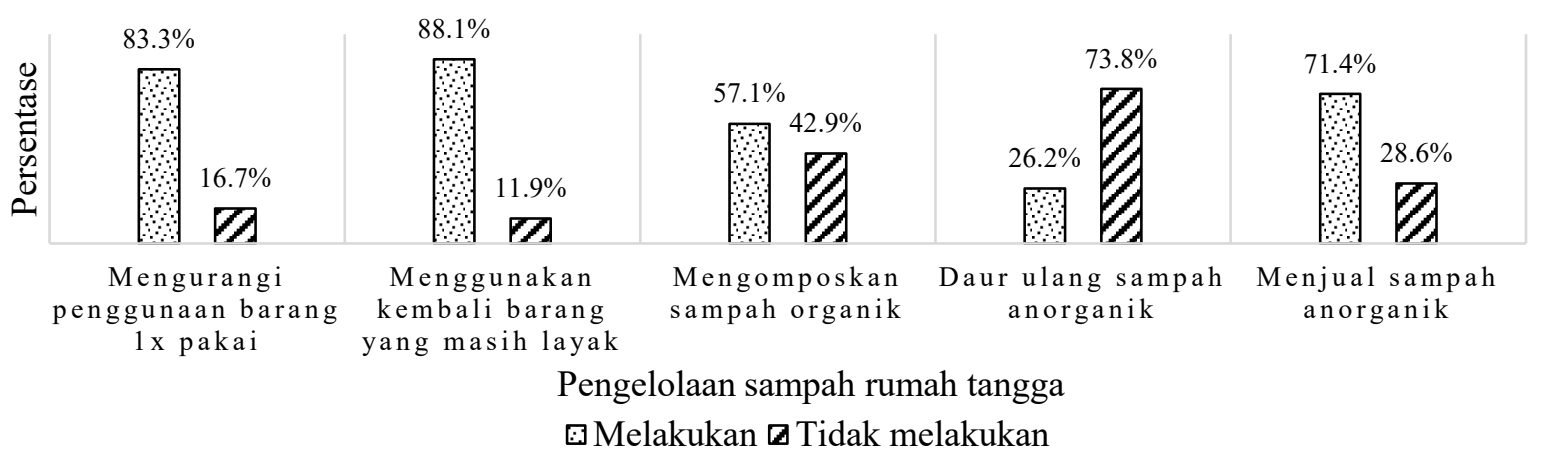

Gambar 3. Perilaku rumah tangga di Desa Sanur Kaja dalam pengelolaan sampah.

Jenis dan Jumlah Sampah yang Dihasilkan oleh Sejumlah Rumah Tangga

Komposisi sampah rumah tangga didominasi oleh jenis sampah organik atau sampah yang mudah membusuk (Dhokhikah et al., 2015). Pada Tabel 1 disajikan persentase responden yang menghasilkan beragam jenis sampah yang diperoleh melalui persamaan 4. Dari 96 rumah tangga sebagai responden dapat diasumsikan bahwa sehari-harinya di Desa Sanur Kaja lebih banyak dihasilkan sampah organik yaitu antara 57,3-93,8\%. Sampah organik yang dihasilkan di antaranya seperti dedaunan, sayuran, bumbu-bumbu, kulit buah, dan sisa makanan dari piring. Sampah anorganik yang dihasilkan seperti tisu, kertas, plastik makanan, kemasan minuman, plastik, kaleng, botol plastik, dan botol kaca sebanyak 11,5 - 87,5\%. Sedangkan sampah residu yang dihasilkan seperti diaper, pembalut, styrofoam dan minyak goreng bekas sebanyak 2,1-67,6\%. Dalam penelitian lain yang dilakukan oleh Ratya dan Welly tahun 2017 di wilayah perumahan Kecamatan Rungkut, sampah organik juga memiliki komposisi yang paling berat di antara jenis sampah rumah tangga yang lain. Persentase sampah organik yang 
dihasilkan yaitu $67,95 \%$, jenis sampah plastik sebanyak $17,1 \%$, sampah kertas sebanyak $14,9 \%$, dan sampah diaper sebanyak 2,5\% (Ratya dan Welly, 2017).

Tabel 1. Jenis sampah rumah tangga yang dihasilkan di Desa Sanur Kaja.

\begin{tabular}{|c|c|c|c|}
\hline No. & Jenis Sampah & $\begin{array}{c}\text { Jumlah } \\
\text { Responden }\end{array}$ & $\begin{array}{c}\text { Persentase* } \\
(\%)\end{array}$ \\
\hline 1 & Dedaunan & 90 & 93,8 \\
\hline 2 & Sayuran & 68 & 70,8 \\
\hline 3 & Bumbu-bumbu & 69 & 71,9 \\
\hline 4 & Kulit buah & 55 & 57,3 \\
\hline 5 & $\begin{array}{l}\text { Sisa makanan } \\
\text { dari piring }\end{array}$ & 79 & 82,3 \\
\hline 6 & Kertas & 42 & 43,8 \\
\hline 7 & Tisu & 83 & 86,5 \\
\hline 8 & Plastik makanan & 84 & 87,5 \\
\hline 9 & Plastik & 51 & 53,1 \\
\hline 10 & $\begin{array}{l}\text { Kemasan } \\
\text { makanan }\end{array}$ & 40 & 41,7 \\
\hline 11 & $\begin{array}{l}\text { Kemasan } \\
\text { minuman }\end{array}$ & 50 & 52,1 \\
\hline 12 & $\begin{array}{l}\text { Wadah/kemasan } \\
\text { plastik }\end{array}$ & 36 & 37,5 \\
\hline 13 & $\begin{array}{l}\text { Wadah/kemasan } \\
\text { kertas }\end{array}$ & 29 & 30,2 \\
\hline 14 & $\begin{array}{l}\text { Botol minuman } \\
\text { plastik }\end{array}$ & 64 & 66,7 \\
\hline 15 & $\begin{array}{l}\text { Kaleng } \\
\text { minuman }\end{array}$ & 40 & 41,7 \\
\hline 16 & $\begin{array}{l}\text { Kaleng } \\
\text { makanan }\end{array}$ & 11 & 11,5 \\
\hline 17 & Botol kaca & 12 & 12,5 \\
\hline 18 & $\begin{array}{l}\text { Minyak goreng } \\
\text { bekas }\end{array}$ & 37 & 38,5 \\
\hline 19 & Styrofoam & 6 & 6,3 \\
\hline 20 & Diaper bayi & 13 & 13,5 \\
\hline 21 & Diaper orang tua & 2 & 2,1 \\
\hline 22 & Pembalut & 65 & 67,6 \\
\hline
\end{tabular}

Keterangan: *Persentase yang tercantum merupakan persentase responden yang menghasilkan setiap jenis sampah rumah tangga dalam satu kali penyebaran kuesioner.

Tabel 2 menunjukkan total sampah yang dihasilkan dalam satu hari oleh 96 rumah tangga di Desa Sanur Kaja yang diperoleh dengan menggunakan persamaan 5. Berdasarkan hasil penelitian diketahui bahwa total sampah rumah tangga yang dihasilkan yaitu rata-rata $\pm 158 \mathrm{~kg} /$ hari sehingga dalam satu hari total sampah yang dihasilkan oleh rumah tangga yaitu $\pm 1,6 \mathrm{~kg} / \mathrm{RT} / \mathrm{hari}$. Pada tahun 2019 tercatat jumlah rumah tangga di Desa Sanur Kaja yaitu sebanyak 1.658 KK (Pemerintah Kota Denpasar, 2020), sehingga berdasarkan hasil perhitungan rata-rata total sampah rumah tangga yang dihasilkan yaitu $\pm 2.652,8$ $\mathrm{kg} / \mathrm{hari}$.

\section{Efektivitas Sistem Pengelolaan Sampah Berbasis Masyarakat}

Perhitungan efektivitas sistem pengelolaan sampah berbasis masyarakat pada penelitian ini dilakukan dengan mencari persen reduksi yang melibatkan jumlah reduksi sampah dan total sampah secara keseluruhan yang dihasilkan dalam satu hari oleh 96 rumah tangga di Desa Sanur Kaja. Reduksi sampah merupakan kegiatan untuk mengurangi timbulan sampah yang dapat dilakukan dengan pemanfaatan kembali, daur ulang, pengomposan dan penjualan sampah anorganik (Kementerian Pekerjaan Umum, 2010). Menurut Suryani (2014), persen reduksi merupakan salah satu indikator untuk mengukur efektivitas pengelolaan sampah yang menunjukkan tinggi rendahnya efektivitas. Semakin besar persen reduksinya maka semakin sedikit sampah residu yang terbuang. Dalam penelitian ini persen reduksi sampah dihitung dengan menggunakan persamaan 6. Pada Tabel 3 tertera jumlah reduksi sampah rumah tangga di Desa Sanur Kaja dalam satu hari yang dikelola dengan cara pengomposan, daur ulang, dan penjualan sampah anorganik. Dari hasil perhitungan diperoleh rata-rata jumlah sampah rumah tangga yang direduksi yaitu $35,5 \mathrm{~kg} /$ hari.

Sampah yang direduksi tersebut adalah sampah yang tidak ikut terbuang ke Depo Cemara. Dengan menggunakan analisa kesetimbangan massa sampah (persamaan 7) diperoleh jumlah sampah residu yang dihasilkan oleh 96 rumah tangga di Desa Sanur Kaja yaitu $122,5 \mathrm{~kg} /$ hari. Sampah residu adalah sampah yang tidak dapat didaur ulang atau dimanfaatkan kembali sehingga harus terbuang (Larasati dan Laila, 2020). Pada penelitian sebelumnya yang dilakukan oleh Radityaningrum et al. (2017), reduksi sampah sebesar $96,5 \%$ di bank sampah BJSC Surabaya dikatagorikan memiliki tingkat efektivitas yang tinggi. Hal ini menunjukkan bahwa efektivitas pengelolaan sampah berbasis masyarakat di Desa Sanur Kaja tergolong rendah karena diketahui terjadi $22,5 \%$ reduksi sampah dalam satu hari sebelum dibawa menuju Depo Cemara. 
Tabel 2. Total sampah (organik dan anorganik) yang dihasilkan di Desa Sanur Kaja dalam satu hari.

\begin{tabular}{ccccc}
\hline $\begin{array}{c}\text { Massa sampah } \\
\text { (kg/hari) }\end{array}$ & $\begin{array}{c}\text { Jumlah responden } \\
(\mathbf{R T})\end{array}$ & $\begin{array}{c}\text { Jumlah sampah } \\
\text { minimal } \\
\text { (kg/hari) }\end{array}$ & $\begin{array}{c}\text { Jumlah sampah } \\
\text { maksimal } \\
\text { (kg/hari) }\end{array}$ & $\begin{array}{c}\text { Rata-rata jumlah } \\
\text { sampah (kg/hari) }\end{array}$ \\
\hline $0,5-1$ & 20 & 10 & 20 & 15 \\
$1-2$ & 57 & 57 & 114 & 85,5 \\
$2-3$ & 14 & 28 & 42 & 35 \\
$3-4$ & 1 & 3 & 4 & 3,5 \\
$4-5$ & 3 & 12 & 15 & 13,5 \\
$>5$ & 1 & $>5$ & $>5$ & 5,5 \\
Total & 96 & \pm 115 & \pm 200 & \pm 158 \\
\hline
\end{tabular}

Keterangan: Jumlah sampah minimal diperoleh dari hasil kali antara massa sampah terkecil dengan jumlah rumah tangga. Jumlah sampah maksimal diperoleh dari hasil kali antara massa sampah terbesar dengan jumlah rumah tangga.

Tabel 3. Total reduksi dan persentase reduksi sampah rumah tangga yang dilakukan di Desa Sanur Kaja dalam satu hari.

\begin{tabular}{lccccc}
\hline \multicolumn{1}{c}{ Kegiatan } & $\begin{array}{c}\text { Jumlah } \\
\text { responden* } \\
\text { (RT) }\end{array}$ & $\begin{array}{c}\text { Jumlah } \\
\text { sampah } \\
\text { minimal } \\
\text { (kg/hari) }\end{array}$ & $\begin{array}{c}\text { Jumlah } \\
\text { sampah } \\
\text { maksimal } \\
\text { (kg/hari) }\end{array}$ & $\begin{array}{c}\text { Rata-rata } \\
\text { jumlah } \\
\text { sampah } \\
\text { (kg/hari) }\end{array}$ & $\begin{array}{c}\text { Persen } \\
\text { reduksi (\%) }\end{array}$ \\
\hline $\begin{array}{l}\text { Pengumpulan bahan } \\
\text { untuk pengomposan } \\
\text { sampah organik }\end{array}$ & 40 & 10,4 & 15 & 12,7 & - \\
$\begin{array}{l}\text { Penjualan sampah } \\
\text { anorganik }\end{array}$ & 61 & 12,1 & 20,4 & 16,3 & - \\
$\begin{array}{l}\text { Daur ulang sampah } \\
\text { anorganik }\end{array}$ & 29 & 5 & 8 & 6,5 & - \\
Total & - & & & & \\
\hline
\end{tabular}

Keterangan: *Jumlah responden yang tercantum merupakan jumlah responden yang melakukan salah satu atau seluruh kegiatan reduksi.

\section{Ekspektasi Masyarakat Desa Sanur Kaja mengenai Pengelolaan Sampah Berbasis Masyarakat}

Berdasarkan Gambar 4, diketahui bahwa masyarakat Desa Sanur Kaja merespon positif terhadap rencana penerapan prinsip 3R pada pengelolaan sampah rumah tangga. Dari 96 orang responden sebanyak 47 responden (49\%) menyatakan setuju, 46 responden $(46 \%)$ menyatakan sangat setuju dan lima responden (5\%) yang menyatakan ragu-ragu. 


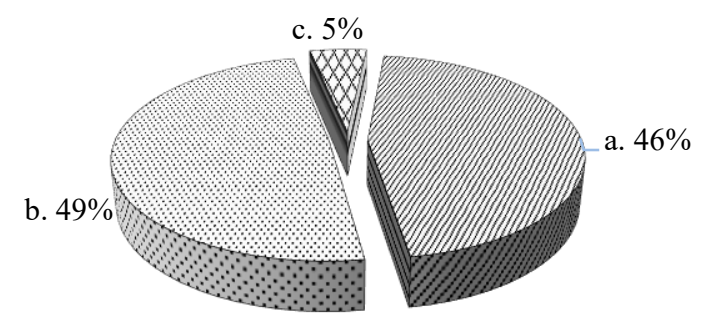

\section{$\square$ a. Sangat setuju $₫ \mathrm{~b}$. Setuju $\square \mathrm{c}$. Ragu-ragu}

Gambar 4. Tanggapan masyarakat Desa Sanur Kaja terhadap penerapan prinsip 3R dalam pengelolaan sampah rumah tangga.

Pada Gambar 5 dipaparkan fasilitas-fasilitas yang dianggap perlu oleh masyarakat untuk mendukung pengelolaan sampah berbasis masyarakat. Fasilitas pengomposan di setiap banjar merupakan pilihan fasilitas yang dianggap paling penting oleh masyarakat dengan persentase $63,5 \%$. Disusul dengan penyusunan jadwal pengangkutan sampah sebanyak $58,3 \%$ yang bertujuan agar pengangkutan sampah tidak terlambat. Membedakan angkutan untuk setiap jenis sampah yang terpilah dipilih sebanyak $54,2 \%$ dan terakhir yaitu pengangkutan sampah panggilan dipilih sebanyak $33,3 \%$.
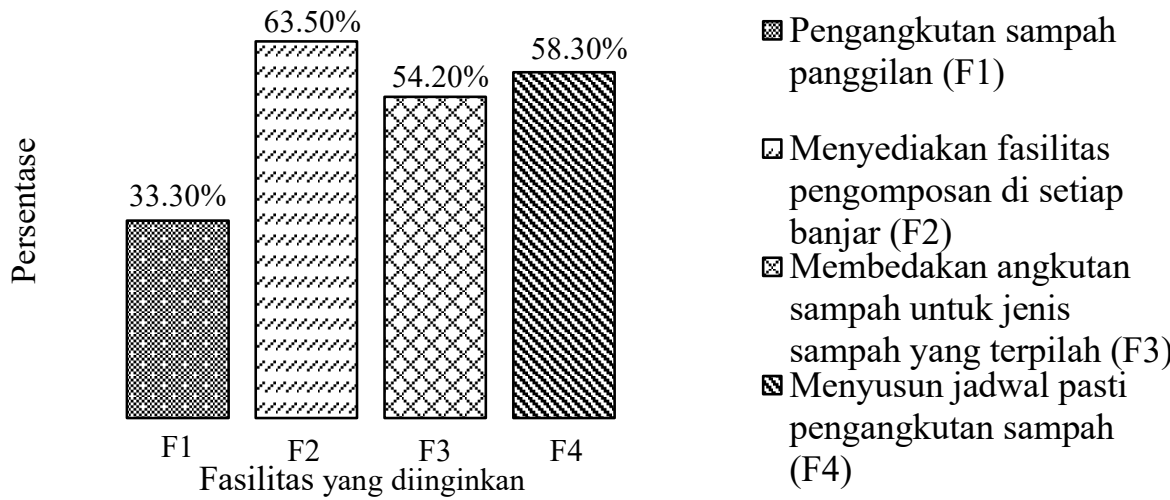

Gambar 5. Fasilitas pengelolaan sampah yang diinginkan masyarakat Desa Sanur Kaja untuk mendukung penerapan prinsip $3 \mathrm{R}$ di rumah tangga.

\section{KESIMPULAN}

\section{Kesimpulan}

Berdasarkan hasil penelitian yang dilakukan terhadap 96 rumah tangga di Desa Sanur Kaja, sebanyak 38\% rumah tangga memilah dua jenis sampah, enam persen rumah tangga memilah tiga jenis sampah, dan $56 \%$ rumah tangga tidak melakukan pemilahan sampah. Rata-rata total sampah yang dihasilkan yaitu $158 \mathrm{~kg} /$ hari sedangkan rata-rata reduksi sampah yang terjadi dalam satu hari yaitu $22,5 \%$. Pengelolaan sampah berbasis masyarakat di Desa Sanur Kaja sudah efektif namun masih tergolong rendah. Sebanyak $49 \%$ responden menyatakan setuju terhadap rencana penerapan prinsip $3 \mathrm{R}$ dalam pengelolaan sampah rumah tangga serta penambahan fasilitas pendukung untuk pengelolaan sampah berbasis masyarakat.

\section{Saran}

Data yang terkumpul pada penelitian ini hanya berdasarkan sudut pandang masyarakat tanpa melibatkan pihak pemerintah desa sehingga untuk memperoleh solusi yang tepat mengenai rendahnya efektivitas pengelolaan sampah berbasis masyarakat perlu dilakukan wawancara dengan pemerintah desa setempat. Selain itu juga dapat dilakukan perencanaan program yang tepat untuk membantu pemerintah setempat dalam meningkatkan efektivitas pengelolaan sampah berbasis masyarakat. 


\section{DAFTAR PUSTAKA}

Badan Pusat Statistik. 2015. Penyusunan Indikator Perilaku Peduli Lingkungan Hidup. Jakarta: Badan Pusat Statistik. https://sirusa.bps.go.id/sirusa/index.php/dasar/p $\mathrm{df} ? \mathrm{kd}=3410 \& \mathrm{th}=2015$

Badan Pusat Statistik. 2018. Laporan Indeks Perilaku Ketidakpedulian Lingkungan Hidup Indonesia 2018. Jakarta:

BPS-RI. https://www.bps.go.id/publication/download.ht $\mathrm{ml}$

Badan Standardisasi Nasional. 2008. Pengelolaan Sampah di Permukiman. Jakarta: Badan Standardisasi Nasional. https://upst.dlh.jakarta.go.id/files/SNI_32422008.pdf

Dhokhikah, Y., Trihadiningrum, Y., dan Sunaryo, S. 2015. Community Participation in Household Solid Waste Reduction in Surabaya, Indonesia. Resources, Conservation and Recycling Journal.

102:153-162. https://doi.org/10.1016/j.resconrec.2015.06.013

Etikan, Ilker., Musa, Sulaiman Abubakar., dan Alkassim, R. S. 2016. Comparison of Convenience Sampling and Purposive Sampling. American Journal of Theoretical and Applied Statistics. 5(1):1-4. https://doi.org/10.11648/j.ajtas.20160501.11

Kementerian Pekerjaan Umum. 2010. Modul Pengolahan Sampah Berbasis 3R. Jakarta: Badan Penelitian dan Pengembangan - Pusat Penelitian dan Pengembangan Permukiman. http://litbang.pu.go.id/puskim/source/pdf/Mod ul\%20Sampah\%203R.pdf

Larasati, N., dan Laila, F. 2020. Analisis Sistem Pengelolaan Sampah Organik di Universitas Indonesia (Studi Kasus Efektivitas Unit Pengolahan Sampah UI Depok). Jurnal Nasional Kesehatan Lingkungan Global. 1(2):85-92.

https://doi.org/http://dx.doi.org/10.7454/jukl.v1 i2.3800

Madrini, B. 2016. Community-based Composting and Management of Leftover Food for Urban Agriculture. Tesis. Tokyo University.https://tuat.repo.nii.ac.jp/?action=re pository_action_common_download\&item_id= $1340 \&$ item_no $=1 \&$ attribute $i d=16 \&$ file no $=1$

Marita, T. 2013. Gambaran Pengetahuan Remaja Tentang HIV/AIDS di Kelas XI SMA Yadika Cicalengka. Skripsi. Universitas Pendidikan Indonesia.

http://repository.upi.edu/6037/6/D3_Per_10089 51_Chapter3.pdf
Pemerintah Kota Denpasar. 2020. Profil Desa Sanur Kaja Tahun 2019. Denpasar. https://sanurkaja.denpasarkota.go.id/download

Putranto, D. M. A. I. S. 2015. Sistem dan Nilai Ekonomi Pengelolaan Sampah di Depo Cemara Desa Sanur Kaja, Kecamatan Denpasar Selatan, Kota Denpasar. Ecotrophic: Journal of Environmental Science. 7(2):144-151. https://ojs.unud.ac.id/index.php/Ecotrophic/arti cle/download/13582/9252

Radityaningrum, A. D., Caroline, J., dan Restianti, D. K. (2017). Potensi Reduce, Reuse, Recycle (3R) Sampah Pada Bank Sampah "Bank Junk for Surabaya Clean (BJSC)." Jukung (Jurnal Teknik Lingkungan). 3(1):1-11. https://doi.org/10.20527/jukung.v3i1.3194

Ratya, H., dan Welly, H. 2017. Timbulan dan Komposisi Sampah Rumah Tangga di Kecamatan Rungkut Surabaya. Jurnal Teknik ITS. 6(2): 451-453. https://doi.org/10.12962/j23373539.v6i2.24675

Riswan, Henna, R. S., dan Agus, H. 2012. Pengelolaan Sampah Rumah Tangga di Kecamatan Daha Selatan. Jurnal Ilmu Lingkungan. 9(1):31-39. https://doi.org/10.14710/ji1.9.1.31-38

Sahil, J., Henie, M., Al, I., Rohman, F., dan Syamsuri, I. 2016. Sistem Pengelolaan dan Upaya Penanggulangan Sampah di Kelurahan Dufa Dufa Kota Ternate. Jurnal Bioedukasi. 4(2):478-487.

https://ejournal.unkhair.ac.id/index.php/bioedu/ article/view/160

Sasanto, R., dan Purwanti, R. 2011. Peran Serta Masyarakat Dalam Pengelolaan Sampah di Lingkungan Perumahan Studi Kasus: Kampung Banjar Sari Kelurahan Cilandak Barat, Jakarta Selatan. Jurnal Planesia. 2(1):80-88. https://ejurnal.esaunggul.ac.id/index.php/plane sa/article/view/538

Setiawan, N. 2007. Penentuan Ukuran Sampel Memakai Rumus Slovin dan Tabel KrejcieMorgan: Telaah Konsep dan Aplikasinya. Makalah disajikan dalam Diskusi Ilmiah Jurusan Sosial Ekonomi Fakultas Peternakan. Universitas Padjajaran. Nopember 2007. http://pustaka.unpad.ac.id/wpcontent/uploads/2009/03/penentuan_ukuran_sa mpel_memakai_rumus_slovin.pdf

Sukerti, N. L. G., Sudarma, I. M., dan Pujaastawa, I. B. 2017. Perilaku Masyarakat dalam Pengelolaan Sampah dan Faktor-faktor yang Mempengaruhi di Kecamatan Denpasar Timur Kota Denpasar, Provinsi Bali. Ecotrophic: Journal of Environmental Science. 11(2):148155.

https://doi.org/10.24843/ejes.2017.v11.i02.p05 
Suryani, A. S. 2014. Peran Bank Sampah Dalam Efektivitas Pengelolaan Sampah (Studi Kasus Bank Sampah Malang). Jurnal Aspirasi. 5(1), 71-84.

https://jurnal.dpr.go.id/index.php/aspirasi/articl e/view/447

Susanto, R., Lailatul, N., dan Pahroni, R. 2010. Hubungan Pengetahuan Terhadap Pengelolaan Sampah Organik dan Non Organik pada Masyarakat RW 03 Sumbersari Malang. Jurnal Keperawatan. 1(1):32-38. http://ejournal.umm.ac.id/index.php/keperawat an/article/view/394

Triana, A. P., dan Sembiring, E. 2019. Evaluasi Kinerja Dan Keberlanjutan Program Bank Sampah Sebagai Salah Satu Pendekatan Dalam Pengelolaan Sampah Dengan Konsep 3R. Jurnal Teknik Lingkungan. 25(1):15-28. https://doi.org/http://dx.doi.org/10.5614\%2Fj.tl .2019.25.1.2

Wardi, I. N. 2011. Pengelolaan Sampah Berbasis Sosial Budaya: Upaya Mengatasi Masalah Lingkungan di Bali. Jurnal Bumi Lestari. 11(1):167-177.

https://ojs.unud.ac.id/index.php/blje/article/do wnload/97/80

Wawan, A., dan Dewi, M. 2011. Teori dan Pengukuran Pengetahuan, Sikap, dan Perilaku Manusia. Yogyakarta: Nuha Medika. http://library.usd.ac.id/web/index.php?pilih=se arch\&p $=1 \& q=0000127353 \& g o=$ Detail

Winarsih, N. W., Candranegara, I. M., dan Mahardhika, I. P. 2019. Efektivitas Pengelolaan Sampah di Kota Denpasar (Suatu Penelitian di Dinas Lingkungan Hidup dan Kebersihan Kota Denpasar). SINTESA: Jurnal Ilmu Sosial dan Ilmu Politik. 10(2):74-77. https://doi.org/http://dx.doi.org/10.22225/sintes a.10.2.1536.74-77 